\title{
SOLUTIONS TO DEVELOPING HUMAN RESOURCES FOR VIETNAMESE LOGISTICS FIRMS IN THE CONTEXT OF ECONOMIC INTEGRATION
}

\author{
Doan Hong Phat*1, Phan Nguyen Xuan Mai \\ ${ }^{1}$ Foreign Trade University, Ho Chi Minh city Branch, 15 D5 Street, Ward 25, Binh Thanh District, Ho Chi \\ Minh City, 700000, Vietnam, doanhongphat.cs2@ftu.edu.vn, (+84944606088) \\ ${ }^{2}$ University of Economics and Finance, 141 Dien Bien Phu Street, Ward 15, Binh Thanh District, Ho Chi \\ Minh City, 700000,Vietnam, maipnx@uef.edu.vn, (+84379099766)
}

\begin{abstract}
Together with the strong development of technology science and globalization trend, logistics activities from production to consumption play more and more important role in competitive ability of firms. However, human resources are still a hard problem to the whole industry. This article generalizes the situation of human resources in logistics industry in Vietnam, and suggests several solutions to developing human resources for this area in the upcoming period.
\end{abstract}

\section{Keywords}

Human resources, logistics, Vietnamese firms

\section{JEL Classification}

E24 Employment; Unemployment; Wages; Intergenerational Income Distribution; Aggregate Human Capital; Aggregate Labor Productivity

J24 Human Capital; Skills; Occupational Choice; Labor Productivity

015 Economic Development: Human Resources; Human Development; Income Distribution; Migration

DOI: https://doi.org/10.14311/bit.2021.01.02

Editorial information: journal Business \& IT, ISSN 2570-7434, CreativeCommons license (c) (1) published by CTU in Prague, 2021, http://bit.fsv.cvut.cz/

\section{Introduction}

In the context of the Industrial Revolution 4.0 taking place strongly with breakthroughs in the field of artificial intelligence, integrating artificial intelligent with networks of internet and modernizing tools is completely changing the prospect of the global logistics industry. The logistics area in the world is shifting the center to developing markets in Asia. Therefore, investing in the technology and human will be the determinants to the development of this industry in the future. At current, Vietnam has many advantageous conditions to become the international sea freight center such as a good position in the axis of the maritime trade; one of four countries of Southeast Asia who has potential to develop both infrastructure and logistics systems; many big opportunities from the trade 
war between the US and China, etc. In addition, the annual growth rate of this industry is above $10 \%$, contributing approximate 5\% to the country's GDP. Therefore, to promote logistics to become a key sector which helps improve the general competitive ability of the whole economy, the Prime Minister signs Decison No.200/QD-TTg which is about the Action Plan to improve competitiveness and develop Vietnam's logistics services until 2025. After this promulgation, several ministries, localities and associations have issued their plans to concretize the tasks to develop logistics services in accordance with the conditions and characteristics of socio-economic development. As a result, Vietnam's seaports have been invested and built on a large scale. They have the capability of receiving ships with the tonnage of over 100,000 tons. Furthermore, at current, 70 international flight routes are being exploited. However, the reality shows that the competitive ability of Vietnam logistics industry is still much limited. Even though the infrastructure together with the management technology and Government policies have been improved for the last years, they need to be promoted more and more to catch up the development speed of the partners and competitors in the area. Moreover, human resources are the biggest problem of the logistics industry currently because Vietnam is facing the shortage and weakness in its human resources due to the hot growth. From the reality, more than $70 \%$ firms encounter difficulties in looking for the human resources, from top senior managers to unskilled workers. This difficulty becomes bigger and bigger when Vietnam took part in Asian Economic Community and new generation free trade agreements. Originating from this context, the article will generalize the current situation of human resources in logistics industry and propose several solutions to developing human resources for Vietnam logistics enterprises in the future.

\section{Methodology}

The issues in this study are mainly analyzed and evaluated by following research methods:

- Statistical method: the study synthesizes data related to human resources in Vietnam logistics enterprises from some sources of secondary data.

- Synthesizing and analyzing method: based on statistics, the article synthesizes and analyzes the situation of human resources in Vietnam logistics industry in the current period. From then, the author proposes several solutions to enhancing the human resources for firms in this industry.

\section{Results}

\section{Current situation of human resources in Vietnam logistics industry}

\subsection{The size of human resources in Vietnam logistics firms}

According to General Statistics Office of Vietnam, the majority of logistics firms in this country has small and super small size. Specifically, out of 34,249 active enterprises, $41.4 \%$ are micro-sized with less than 5 employees; $53.74 \%$ are small sized with less than 50 employees; $4.12 \%$ have medium size with less than 300 employees. The number of large enterprises accounts for only $0.7 \%$. 
Table 1. The logistics industry by human resources size in Vietnam (source: General Statistics Office of Vietnam, 2018

\begin{tabular}{|l|l|l|l|l|l|l|l|l|l|}
\hline & $<5$ & $5-9$ & $\begin{array}{l}10- \\
49\end{array}$ & $\begin{array}{l}50- \\
199\end{array}$ & $\begin{array}{l}200- \\
299\end{array}$ & $\begin{array}{l}300- \\
499\end{array}$ & $\begin{array}{l}500- \\
999\end{array}$ & $\begin{array}{l}1000- \\
4999\end{array}$ & $\begin{array}{l}>500 \\
0\end{array}$ \\
\hline $\begin{array}{l}\text { Railway, road, and } \\
\text { pipeline transport }\end{array}$ & 7400 & 6451 & 5886 & 647 & 65 & 58 & 37 & 10 & 3 \\
\hline Waterway transport & 463 & 423 & 675 & 140 & 12 & 14 & 4 & 3 & 0 \\
\hline Air transport and & 1 & 0 & 0 & 0 & 1 & 0 & 1 & 2 & 1 \\
\hline $\begin{array}{l}\text { Warehousing activities } \\
\text { supporting } \\
\text { for transport. }\end{array}$ & 5923 & 2509 & 2109 & 447 & 54 & 50 & 27 & 12 & 3 \\
\hline Post and delivery & 397 & 214 & 141 & 17 & 4 & 6 & 7 & 3 & 2 \\
\hline Total & 14184 & 9597 & 8811 & 1278 & 136 & 128 & 76 & 30 & 9 \\
\hline
\end{tabular}

According to the table above, employees working in railway, road and pipeline transport firms account for the highest proportion (with a percentage of $60.1 \%$ ) of the total number of employees working in the logistics industry. Followed are workers in the warehouse and transportation support activities (32.51\%); waterway transportation (5.06\%); post and delivery (2.31\%). Labor in the air transport sector accounts for the lowest proportion of $0.02 \%$.

\subsection{Logistics human resources quality}

In recent years, with the new development of the logistics service market, Vietnamese logistics human resources' strength lies in its being young, dynamic, adventurous and willing to accept challenge and take risks. However, Vietnam still must deal with logistics human resources lacking in quantity, in expertise and professionalism. In addition, the preparation in knowledge, skills, attitudes as well as the psychological state of Vietnam's logistics workers for the labor movement among ASEAN countries is unqualified. Lack of labor discipline, legal compliance awareness as well as low labor intensity are also weaknesses calling for solutions in the time to come. Particularly, the strengths and weaknesses of the current four levels of logistics human resources in Vietnamese firms are as follows:

- The management group (including members of the board of directors and board of management) is mostly experienced in business, has a wide business network (including international partners), has been trained to meet management needs from time to time. However, this group lacks indepth knowledge. These people acquired knowledge mainly from practical business experiences or from the process of working as an agent or partner with foreign logistics enterprises. Hence, they are not well prepared enough for operating internationally or developing new service areas. Some also lack foreign languages skills or have to be responsible for too many positions. Future challenges for the management team are mainly catching up with new technologies and diversifying services, developing regional and global visions, capturing logistics information and international trade, and the ability to plan for sustainable development.

- The group of managers and supervisors (including department managers and supervisors or team / group leaders) are people with practical experience in operating, and good expertise. However, most of them lack in-depth knowledge due to lack of systematic training. Only about less than $10 \%$ are trained in the right industry, have basic knowledge, and hence, are considered quite sharp, creative, and knowledgeable about the market. Besides, it is also said that this group lack human resources management and job management skills, have inadequate English and information technology skills, with unsatisfied ability to coordinate, cooperate, adapt, create and 
to meet with customers' needs. They don't have much experience in working with international partners, and are hardly ever updated with new knowledge.

- The group of staffs (office, field) mostly graduated from university but mainly in majors completely different from or just slightly close to logistics. The biggest weakness of the logistics human resources logistics in this level is that they are not good at foreign languages; lack of commitment to long-term working with the business, poor regulatory and process compliance; lack of innovation and professionalism ... In the future, foreign languages and ability to communicate, team coordination, expertise, modern working manners and customer care service skills will be big challenges they have to face.

- The group of labor working directly at transportation firms, warehouses and factories are mostly trained from vocational schools. Their main work is loading and unloading goods, inventory at warehouses, and controlling means of transport or specialized equipment in the logistics sector. Despite being trained, the working skills of this group are unsatisfactory, in other words, they lack industrial manner, labor discipline compared to direct labor in some other developing countries such as Thailand, Malaysia, ...

According to the research team of Foreign Trade University, about $60-80 \%$ of enterprises surveyed said the availability of skilled logistics manpower at all levels from workers directly to the staff. Currently, administrators in Vietnamese businesses are mostly low and average.

Table 2. The availability of skilled logistics human resources in Vietnam (source: Ministry of Trade and Industry, 2019)

\begin{tabular}{|l|l|l|l|l|l|}
\hline & N/A & Low & Average & High & Very high \\
\hline Driver & 3.6 & 19.6 & 48.2 & 28.6 & 0 \\
\hline Forklift controller & 0 & 21.4 & 55.4 & 23.2 & 0 \\
\hline Warehouse operation & 5.4 & 28.6 & 41.1 & 23.2 & 1.8 \\
\hline Packing & 8.9 & 17.9 & 39.3 & 30.4 & 3.6 \\
\hline Consulting & 1.8 & 12.3 & 36.8 & 36.8 & 10.5 \\
\hline Customs broker & 5.3 & 17.5 & 59.6 & 15.8 & 1.8 \\
\hline Logistics planning & 3.6 & 44.6 & 30.4 & 19.6 & 1.8 \\
\hline Forecasting & 15.8 & 42.1 & 24.6 & 15.8 & 1.8 \\
\hline Inventory planning & 8.9 & 33.9 & 41.1 & 16.1 & 0 \\
\hline Transportation planning & 7.1 & 33.9 & 42.9 & 14.3 & 1.8 \\
\hline Stacking planning & 5.4 & 32.1 & 33.9 & 28.6 & 0 \\
\hline Logistics / supply chain analysis & 5.4 & 39.3 & 35.7 & 19.6 & 0 \\
\hline Operational management & 1.8 & 28.6 & 50 & 17.9 & 1.8 \\
\hline Warehouse management & 1.8 & 25 & 51.8 & 17.9 & 3.6 \\
\hline Retail management & 1.8 & 25 & 58.9 & 8.9 & 5.4 \\
\hline Customer services management & 1.8 & 14 & 52.6 & 28.1 & 3.5 \\
\hline $\begin{array}{l}\text { Business development } \\
\text { management }\end{array}$ & 3.6 & 28.6 & 42.9 & 25 & 0 \\
\hline $\begin{array}{l}\text { Logistics and supply chain } \\
\text { management }\end{array}$ & 7.1 & 32.1 & 32.1 & 28.6 & 0 \\
\hline
\end{tabular}

\section{Causes of the insufficient and weak logistics human resources in Vietnam}

First, we have had the university level logistics major code, but it is placed in the level IV training code at university level. The Ministry of Education and Training issued Circular No. 24/2017/TTBGDĐT dated October 10, 2017, which came into effect on November 25, 2017, about the List of 
Education and Training Level IV at the University level, in which the code of logistics and supply chain management with Master and PhD degrees is included. That is to say, schools that are not part of the industrial management sector cannot open programs related to logistics and supply chain management. This is unreasonable because in reality logistics and supply chain management are not only related to industrial management and industrial technical infrastructure, but also in other fields such as economics, foreign trade, and law, .... Over the past few years, many other related majors have been trained by the schools, such as freight forwarding, insurance at Foreign Trade University, economics and trade at other economics universities, which as a whole have contributed to the overall training capacity of the logistics industry. Therefore, it is unreasonable if only schools in the industrial management and infrastructure sectors are allowed to open undergraduate and graduate training programs related to logistics and supply chain management.

Second, the training program of logistics in Vietnam still lacks the practical part. Human resources training for the logistics service sector at the university level today is mainly at trade and transportation industry institutions. Particularly, the University of Transport has many majors in transportation operations such as road, railway, multimodal transport and has recently opened a major in logistics management; University of Transport Technology has majors in logistics and multimodal transport; Maritime University has specialize in logistics training; Ho Chi Minh City University of Transport has majors in Logistics Management and Multimodal Transport; The Ho Chi Minh City University of Technical Education opened Logistics and Supply Chain Management in 2016; International University - National University of Ho Chi Minh City has opened Logistics Engineering since 2015. The total number of students trained at these institutions is over 500 students per year. Additionally, schools in the economic and foreign trade sectors such as: Foreign Trade University, National Economics University, RMIT University, Viet Duc University, International University, ... have training majors related to the field of logistics, but these schools only teach freight forwarding and foreign trade insurance, mainly focus on sea freight and sea freight forwarding. In addition, colleges, vocational schools, training centers and businesses have also actively participated in training human resources for the logistics industry. However, in general, these training institutions are weak in terms of expertise, lack of lecturers and face many difficulties in enrolling new trainees. The activities of associations and professional unions have also contributed greatly to the training of human resources for the logistics industry. For example, Vietnam Association of Logistics Services has organized a training program of international standards of FIATA. The International Transport Management Program has been implemented by the Association for 6 years with 25 courses and has trained more than 500 trainees. Besides, there have been many firms conducting basic training on logistics in order for their employees to meet the requirements of logistics-related jobs. However, these businesses have to deal with the problem of self-sufficiency, and hence, they do not have enough resources to invest and develop in a large and methodical scale.

Third, there are not many references and textbooks about this type of service. Even the number of experts trained professionally in this field are still too few compared to the actual development needs of this service industry in Vietnam. The survey results of the current situation of logistics human resource training in Vietnam by the Vietnam Logistics Research and Development Institute in 2017 showed that $86 \%$ of the respondents having said that there was a shortage of logistics lecturers at universities. Another issue worth mentioned is the lack of practical part in training programs. The survey results of Vietnam Logistics Research and Development Institute also showed that according to $57 \%$ of the surveyed people, there is a lack of chance for lecturers and students to study real-life experience and in another $71 \%$ of surveyed people's opinions, schools do not have enough facilities for specialized experiments. This means that students still mainly study theoretically and have little chance to practice. Therefore, upon graduation, students are not able meet the job requirements in 
the logistics service industry. That forces businesses to train again, leading to a costly as well as time consuming situation for businesses.

Fourth, businesses lack initiative in logistics human resources investment and development. In specific, they rarely publicize their recruitment needs, and hardly ever participate in job fairs, therefore, they do not know where the potential employees are. In addition, these businesses also do not have regular and long-term recruitment plans, but often hire only when needed and only deal with immediate requirements rather than long-term development plans. Besides, their job requirements are not clear and professional factors are not considerably treated. Therefore, the recruitment process is often influenced by acquaintance rather than recruiting talented and capable graduates from top universities. In addition, the majority of logistics firms do not have competitive remuneration and benefits. In other words, there is a lack of fair treatment, of training process and of long-term welfare for employees. These problems lead to employees not being motivated or encouraged to acquire more knowledge and skills to become more professional. In fact, despite increasing investment in logistics human resources training, businesses have yet to coordinate effectively with training institutions in organizing internships for students, which is significant in quality assurance of training institutions "output" - the "input" of businesses.

Fifth, the majority of students do not have specific job-oriented goals when choosing majors, so they often lack the orientation and skills needed after graduation. At the same time, students have not proactively researched the needs of employers and approached logistics firms while still at school. Hence, they do not know what skills to prepare for the job after graduation.

\section{Some solutions to improve human resources for businesses in the logistics service industry}

First of all, expanding and upgrading existing training programs. Vietnam needs to expand the logistics major at universities with related fields such as Universities of Law, Finance, Foreign Trade, Economics, Trade, ... and at the same time, establishes separate logistics schools and training institutions. In addition, the consulting process for students to choose suitable majors in the logistics disciplines when preparing for the entrance exam to university also plays an important role. In fact, while this industry has prospects of developing in the future and has many benefits, many students and their parents do not have enough information.

In addition, schools need to encourage their faculty to develop or cooperate and associate with reputable foreign schools and logistics companies in developed countries such as Japan, Korea, Singapore, .... The schools can also train their faculty as well as students by inviting logistics experts to exchange ideas, information, share experiences, give seminars, ... in order for Vietnamese logistics human resources keeps up with the world logistics development.

Moreover, universities need to consult developed countries on the development of training programs and curriculum systems, and reference documents for logistics and supply chain management training. Besides, schools need to connect with specialized businesses to organize field trips and internships for sophomores and juniors, so they can experience reality, have a clearer view of their future career prospects and career requirements. Then, they can orient themselves better in studying and researching, as well as in career development after graduation.

Furthermore, there is a need to continue to promote the role of medium and short-term training programs implemented by training institutes, centers, associations and companies. These organizations should be encouraged to plan and cooperate in training with foreign experts or organizations in countries that have developed and efficiently operated logistics services. These short courses should focus on specialized areas of the profession or on a specific task of the job, or training general knowledge, or advanced knowledge for managers, both intermediate and advanced level. 
Along with the training supports from associations, organizations and universities, logistics businesses need to have policies to train staffs, promoting the strength of their own human resources, in the context of sustainable long-term development. To do this, there are some practical and detailed policies for businesses, such as:

- First, assign human resources to specialized departments in accordance with their training profession and their capacity; review and re-evaluate the entire human resources in fields such as education, gender, training level. Consequently, formulate training programs to improve professional qualifications, and skills for employees.

- Second, develop professional qualifications and skills in logistics activities. Create conditions for employees to learn and work to acquire knowledge and experience from practice; to apply science and technology in the implementation of customs procedures; clearly define training objectives, develop training plans, ....

- Third, raise employees' awareness to meet the development requirements of the firms, creating a growing awareness demonstrated through positive attitudes, right behavior at work, and other social relations.

- Fourth, motivate employees to achieve, contributing to improving productivity, quality and efficiency at work, ....

\section{Conclusion and discussion}

Facing the issue of human resources for the logistics industry in Vietnam in the context of ongoing economic integration, the training of high-quality human resources has become more and more urgent. This work requires proactive participation and commitment of related parties including the Government, local governments, logistics companies, universities and vocational schools. With the practical solutions proposed above, the authors hope that the human resources problem will be solved soon, contributing to improving the competitiveness of Vietnam's logistics industry.

\section{References}

[1] Ahn, Y. S., \& McLean, G. N. (2008). Competencies for port and logistics personnel: An application of regional human resource development. Asia Pacific Education Review, 9(4), 542-551.

[2] Boudreau, J., Hopp, W., McClain, J. O., \& Thomas, L. J. (2003). On the interface between operations and human resources management. Manufacturing \& Service Operations Management, 5(3), 179-202.

[3] Budhwar, P. S., \& Sparrow, P. R. (1997). Evaluating levels of strategic integration and devolvement of human resource management in India. International Journal of Human Resource Management, 8(4), 476-494.

[4] Decision No. 200/2017 / QD-TTg of the Prime Minister promulgating the Action Plan to improve competitiveness and develop Vietnam's logistics services up to 2025.

[5] Huo, B., Ye, Y., Zhao, X., \& Shou, Y. (2016). The impact of human capital on supply chain integration and competitive performance. International Journal of Production Economics, 178, 132-143.

[6] Jurčević, M., Štancl, I. O., \& Ivaković, M. (2012). Human resources management systems in the logistic chain. TRANSPORT ENGINEERING, 323.

[7] Ministry of Trade and Industry (2017), Vietnam logistics Report 2017: From plan to action.

[8] Ministry of Trade and Industry (2019), Vietnam logistics Report 2019: Increase value of agricultural products.

[9] Trinh Thi Thu Huong (2016), Training and developing Logistics human resources in Vietnam, Foreign Trade University.

[10] Website of General Statistic Office of Vietnam: http://www.gso.gov.vn.

[11] YIN, S., \& XIE, S. X. (2006). Research on human resource management innovation for logistic enterprises [J]. Journal of Liaoning Technical University (Social Science Edition), 6. 